\title{
LOOKING INTO FOLKLORES OF PUNJAB THROUGH GURU NANAK'S TRADITION OF MUSIC
}

\author{
Dr. Narendra Kaur
}

Associate Professor, RRMK Arya MMV Pathankot

ABSTRACT

Shri Guru Granth Sahib, as we all know is the holy scripture of sikh community. Hymns in Shri Guru Granth Sahib are called Gurbani. Gurbani is regarded as spiritual and heavenly. It reveals all about almighty God. Gurbani is arranged mainly in thirty one ragas. On one hand, it acquaints us with the ragas of that period while on the other hand it includes the element of folk music also. Many social evils and worthless rituals have been addressed in Gurbani giving examples of folklores only, so as to reach the folks and make the appeal strong and influential as well. Nine tunes of folk-ballad singing are incorporated in Shri Guru Granth Sahib by the sixth Guru, Guru Hargobind Sahib to encourage and enthuse His followers to fight against tyrant Mughals. Gurus used the titles of some folk singing styles prevalent at that time like Alahuniya, Vanjara, Chhant, Chaubole, Din-Rean, Ghoriyaan, Mangal, Karhale, Kafi, Pehre, Ruti, Sadd, Birhade, Anjali, Barah Mah etc. in Guru Granth Sahib reciting Gurbani to give the right knowledge while enlightening the masses against the superstitions and social evils. This paper is aimed at exploring the folklores of Punjab popular during those days through the tradition of Guru nanak's music.

Keywords

Folklores, Guru Nanak, Gurubani

\section{INTRODUCTION}

Folklore consists of traditional customs, music and dance forms, tales, sayings, rituals, art forms, beliefs and the superstitions of a society. Folklore represents our culture and heritage. The state of Punjab is very rich in its culture and heritage. The Guru Nanak's tradition of music, generally, known as 'Kirtan'or 'Gurmat Sangeet' is more than five hundred years old.

Gurmat sangeet being cultural heritage of sikh community of our country, needs to be addressed on academic stage. This art is emerging as a subject of study now-a-days, though has been practised since the times of Gurus. Presently there have been some sorts of research going on to unfold issues regarding its theory and practice. Recently about 8-10 years ago a research study center on Sri Guru Granth Sahib was established with funding from UGC at Guru Nanak Dev university Amritsar while a full-fledged department of Gurmat Sangeet has been founded at Punjabi university Patiala.

Guru Nanak visited all over India during His Udasis (religious travels). During His visits He kept on singing with the accompaniment of Bhai Mardana's Rabab. In His hymns along with spiritual contents there lie many social and cultural issues of various communities. Whatever He sang was an intended creation for the welfare of humankind. Guru Nanak and His follower Gurus continued this practice of spreading spiritual message to society; and till date, kirtan is considered to be a very strong medium of communication to God. All of the Gurus 
sang their hymns in ragas. Along with the ragas of Indian Classical Music, They also used ragas like Vadhans dakhni, Gauri dakhni, Majh, Tukhari, Asa, Tilang etc.belonging to local areas. Where ever Gurus travelled, they addressed the blind faiths and mal-practices of that particular society and showed the right path to people. For example at page no. 1150 Guru writes, "Har simrat kichh chakh na johe" means no one can cast an evil eye upon you if you remember Lords name. At page no. 401, the Guru writes, "Sagun apsagun tis kou lage jis cheet na ave" means good omens and bad omens affect those who do not keep Lord in mind. The content of their hymns at many places shows the folklores prevalent during that period. They in their creations never ignored the folk, whether it is the singing style or the raga forms, the tala, the poetical contents etc. They included the regional affairs of the folks. Ashtapadian, choupade, dupade, Ghorian, Alahunia, Varan, chhanda etc, included in Sri Guru Granth Sahib, depict the trends of the folks of that particular period \& area. Among these, Vaar (ballad) singing style has a special place for featuring the folk tales. Generally, dhadis (vaar singers) in Punjab used to sing Vaars in praise of warriors. Vaars in Sri Guru Granth Sahib are titled along with their tunes naming like 'Tunde Asraje ki dhuni', 'Sikander Birahim ki Vaar ki dhuni', 'Moose ki vaar ki dhuni', 'Rane Kailash tatha maalde ki dhuni', etc. The word 'vaar' has its roots in Sanskrit word 'varta' which means an incident. During those days whenever such an incident of fight of valorous persons happened to be occurred, the dhadis (ballad singers) of those days would disseminate them in the form of poetry and sing that poetry in a particular heroic form of singing. After the martyrdom of Guru Arjan Dev ji, Guru Hargobind Singh wore two swords; one of Miri and the other of being Piri. He decided not to bow before tyranny of mughals but to fight for justice and kill the enemies. When Bhai Abdullah and Bhai Natha, the popular dhadis of that time, presented these vaars of bir-ras in front of Guru Hargobind Sahib at Akal Takhta Sahib, Sri Amritsar, the Guru liked nine of those tunes to be included in Sri Guru Granth Sahib Ji. These tunes are associated with the wars which took place at that time. They give us the message of triumph of true person and fill us with the feeling of courage. It is therefore that the Guru chose those tunes and placed them at the Paudies of Sri Guru Granth Sahib. Out of a total of 22 Vaars included in Sri Guru Granth Sahib, nine have headings of different folktunes (dhun) on which they must be sung.

Similarly, Alahunia were the mournful songs sung by women when someone died. Women would cry and sing in chorus in praise of the deceased. There were professional women called nain who used to be called to lead the morning songs. Since this was a quite un-natural and dramatic expression, so, Guru Nanak wrote 
five hymns in Vadhans raga in which he explained about the mortality of life and emphasized on the utilization of life for spiritual enlightenment and salvation. Physical life is transitory but the soul never dies because it is part of God. Guru expounds the transitory nature of human existence and the inevitability of death. The Guru reformed the funeral practice. In place of weeping he advised his followers to recite gurbani at the time of death so that the departing soul may rest in peace. Nevertheless, there are so many hymns which give us knowledge of the folklore of those days.Through the musical hymns of Guru Granth Sahib, we still have the practical approach to the culture of the period from $15^{\text {th }}$ to $17^{\text {th }}$ century, because there are legendary kirtankars and rababis who are practising it for a number of generations. They have learnt this art from their fathers and fore-fathers Sina-b-Sina (face-to-face). With this we get a chance to understand the actual folk music and culture of those days. Folklores popular those days, included in Sri Guru Granth Sahib are as follows-

Alahuniya: gurbani written under the title of 'Alahunia' by Guru Nanak to point out the transient nature of the human existence and to be recited at the time of funeral. The composition is emotionally charged.

Aarti: the practice of moving a lamp with a number of burning wicks, or a platter with several small lamps in a circular motion in front of an idol or revered person. A song of praise may be sung as aarti is performed. Instruments used during the aarti are dholak, khartaal, ghungaroo, shankh, mridang, toorhi, etc. In place of mere physical practice Guru Nanak advised to sing praises of God Who has given us this beautiful nature which at its own performing Aarti, so need not to collect so many things but to remember God in your heart .Aartis composed by Guru Nanak Dev, bhagat Kabir, bhagat Sen, bhagat Pipa, bhagat Dhanna and bhagat Ravidas are included in the Guru Granth Sahib.

Anjali: offering water to gods and the ancestors is called anjali. Two anjali compositions of Guru Arjun in Maru raag have been included in the Sri Guru Granth Sahib.

Barah Mah: the words mean "12 months"; the composition is in 12 parts each named after a month. Guru Nanak composed His Barah Maah in Tukhari raag and Guru Arjun Dev ji composed it in Majh raag. Under this title Guru Nanak Dev Ji explained condition of the beloved soul in all the twelve months of a year. (Prem Prakash Singh, 1969:232) 
Bavan Akhri: the words mean "52 letters". (The Devnagiri script contains 52 letters.) Bhagat Kabir Das and Guru Arjun Dev have used this form of composition in raag Gowdi.

Birhade: means "separation". Guru Arjan Dev composed three chhands in Aasa raag with the stipulation that they be sung in the chhant style.

Chaubole: a form of composition in which four languages are used. In Sri Guru Granth Sahib there are 11 shalokas of Guru Arjun Dev under the heading of choubolae.

Chhant: a folk form heard during marriages extolling the beauty and desirability of the bride. In the Gurbani the chhant is composed in ragas like Asa, Gowdi, Vadhans, Dhanasri, Tukhari, Bilawal, Suhi, Sri, etc.

Dukhre: a Sindhi word meaning dhol (large drum). Shaloks sung to the beat of the dhol are called dukhre. Guru Arjan Dev has used dukhre in Maru raag. Five other dukhre have been written in Sri Raag.

Ghoriyaan: a joyful song sung just before the bridegroom mounts his decorated horse (Ghori) and leaves for the house of his bride, Guru Ramdas has used the folk elements of the Ghoriyaan in raag Vadhans.

Mangal: this word means "auspicious", a mangal song is sung on happy occasions. Guru Ram Das composed this form in Bilawal raag.

Karhale: a Sindhi word meaning "camel rider", this is a traveller's song. Guru Amardas has composed two shabads under the title of karhale in raag Gowdi and Gowdi Poorvi.

Kafi: devotional song used in Sufi worship. In Guru Granth Sahib kafi has been composed in raags like Asa, Tilang, Suhi and Maru.

Pehre: refers to the four divisions of the day and symbolises the four stages of a man's life. This form is associated with gypsies. Guru Nanak Dev, Guru Ramdas and Guru Arjun have composed pehre in Sri raag.

Ruti: is the plural of Hindi word ritu, meaning "season". India has six seasons, so ruti shabads dscribe the idea that there is not any specific season to concentrate and meditate upon Supreme God.Guru Arjun Dev has written it in Ramkali raag.

Sadd: a song of lament. Before leaving for His heavenly abode Guru Amardas told His family members and followers the truth of this life, the reality of death by explaining death as a way leading to God. Only after death one meets the 
Almighty. Sadd in raga Ramkali was composed by Baba Sundar, the grandson of the Guru on the demise of Guru Amardas. (Dr. Joshi Jeet Singh., 2004:245)

Sohela: a song of rejoicing often sung at the birth of a son, usually on the sixth or twelfth day. Sohela is also called mangal. Though sohela is a song of rejoicing, in Gurmat 'Sohela' is recited at night, a prayer before sleeping and also during the ritual of the death sanskaar.

Tithi: from the Sanskrit word tithi meaning dates of the calendar. The 15 compositions of tithi mirror the 15 days from new moon to full moon, the stanzas are called chhand. Guru Nanak Dev composed tithis in raag Bilawal and Kabir composed them in raag Gowdi.

Vanjara: this word means "gypsy" and reflects the musical style of nomadic tribes that roamed India in medieval times. Guru Ram Das has composed it in Sri raag.

Vaar: the word has its roots in Sanskrit language which means vaarta or an incident. Those days Dhadhis, the folk singers used to sing in potical form the heroic deeds of warriors. A vaar commemorates brave deeds and lives of heroes. The Gurus composed 21 vaars in various raags. The 22 nd vaar was composed by Satta Balwanda singers in the court of Guru Arjan Dev ji. The characteristic of the 9 vaars in the Guru Granth Sahib is that they have been given along with the instruction of how they are to be sung on the basis of popular folk compositions. Vaars are sung in some particular tunes called folk ballads. (Singh Sukhwinder, 2003:13) There are nine vaars in the Guru Granth Sahib having their titled tunes, namely:

- Vaar Majh: Tune of Malak Mureed and Chandrahada Sohiya ki vaar

- Vaar Asa: Tune of Tunde Asraje ki vaar

- Vaar Gowdi: Tune of Rai Kamaal di Mojdi ki vaar.

- Vaar Gujri: Tune of Sikander Birahim ki vaa

- Vaar Vadhans: Tune of Lalla Bahalima ki vaar

- Vaar Ramkali: Tune of Jodhe Veere Purbani ki vaar

- Vaar Sarang: Tune of Rai Mahme Hasane ki vaar

- Vaar Mallaar: Tune of Rane Kailash Tatha Malde ki vaar

- Vaar Kanada: Tune of Moose ki vaar. 
These nine vaars are directed to be sung according to folk tunes or dhunis or taraz indicated upon them. Folk music should not be regarded as inferior to classical music. Both speak the same language, but at different levels. The vaars containing salokas and pauris are generally sung in the raga indicated at the top along with folk style. The martial tunes (dhunis) of nine vaars indicated in the Scripture were known to the singers of that period. The beginning lines of their poetical content are as follows-

(1) Vaar Majh ki tatha salok mahala I Malak Murid tatha Chandrahada Sohiya ki dhuni gavni- Text of the original taraz: Kabul vich murid khan fadya vadh jor. Beginning of Gurbani: Tu karta purakh agamm hai aap srisht upati.(138)

(2) Gaudi ki vaar mahala V Rai Kamaldi Maujdi ki dhuni upar gavni- Text of the original taraz: rana rai kamaldi ran bhara bahin, maujudin talvandion chadhya sabahin. Beginning of Gurbani: Jo tudh bhave so bhala sach tera bhana.( 318)

(3) Asa ki vaar Mahala I Tunde Asraje ki dhuni- Text of the original taraz: Bhabhikiya sher sardul rai run maru wajay. Beginning of Gurbani: Aapeenay aap sajiyo aa peenay rachio nav (p.462)

(4) Gujri ki Vaar, Mahala III Sikandar Birahim ki vaar ki dhuni gauni- Text of the original taraz: Paapi khan birahim par chariya Sekandar. Beginning of Gurbani: Aapna aap upaaon tadoh hor na koi (p.509).

(5) Vadahans ki vaar, Mahla IV Lallan Behleema ki dhuni- Text of the original taraz: Kal lala day desh daa khoiaa bahlima. Beginning of Gurbani: Tu aapayhi aap aap hai aap karan keeaa (p.585).

(6) Ramkali ki vaar Mahla III Jodhay Veeray Poorbani ki dhuni- Text of the original taraz: Jodhe veer poorbanie do gallan karay karaaria. Beginning of Gurbani: Sachay takhat rachaiya baisan kou jaaee (p.947).

(7) Sarang ki vaar, Mahla IV Rai Mehme Hasne ki dhuni- Text of original taraz: Mehma hasna rajpoot rai bharay bhatti. Beginning of Gurbani: Aapay aap niranjana jin aap upaaiya (p. 1237).

(8) Malar ki vaar Mahla I Rane Kailash tatha Malde ki dhuni- Text of the original taraz: Dharat ghora parbat palan sirr tattar umber. Beginning of the Gurbani: Aaapeenay aap saaj aap pachhaniya. (p. 1279).

(9) Kanhde ki vaar, Mahla IV Musay ki var ki dhun- Text of the original taraz: Trai sai sath marataba ik guriye daggaiy. Beginning of Gurbani: Tu aapay hi sidh sadhko, tu aapay hi jog jogia (p. 1313) 
Analysis-Folk music has a wider appeal and it acquires a refined character when it is welded with classical music. Those who do not know raga can sing hymns in sadharan or jotiyan tune. It seems that guru Nanak chose this way to communicate to the folks as He knew that folk music has a very strong appeal and influence. Asa-ki-vaar is to be sung in raga Asa which is classical, while the dhuni is that of the popular vaar of Tunda Asraja. A vaar is generally intended to produce a heroic and martial feeling-Bir rasa. Its diction is simple but emotional. Asa-ki-vaar contains pauris (of Guru Nanak) of five line each, along with His slokas. The slokas of Guru Angad were added later on to it by Guru Arjan Dev ji. Chhants of Guru Ramdas ji were directed to be sung with Asa-ki-vaar of Guru Nanak, by Guru Arjan Dev ji on account of the similarity of contents. Just as the theme of the vaar of Tunda Asraja is the victory of good over evil, in the same way, the subject of Asa-ki-vaar is spiritual evolution and fulfilment. Hurdles in the path of divinity, like ego, hypocrisy and evil thoughts are conquered by following the path of truth and meditation and the earning of God's grace. The musical effect of this 'Ballad of Hope' is extremely blissful. Instead of the clash of arms, we find in the vaars of the Gurus the clash of ideas. The vaars have spiritual content though they follow the tune of folk-ballads popular those days. There is a clash between truth and ritual, piety and hypocrisy. (Mansukhani, G.S. 1982: 102)

The expression of religious culture of Sikh community needs to be extended in the subject of Anthropology of India. If bonded with academics; the cultural heritage of folk tunes and their related affairs will get a boost for their preservation and conservation for future growth and development of our society. Since man is a social creature, anything he does affects the society and the coming generation, directly or indirectly. Skills and arts in their original forms are generally transmitted one-to-one. The Gurus included the folklores to make gurbani understandable to everyone in the society. In a very simple way they showed us the path to follow in our life to achieve bliss, peace and salvation. It is only gurbani which unfolds the mystiques of spirituality. The Gurus chose the medium of folk music as well as classical music to express them so that even a common man of an average mental level can comprehend the spiritual thoughts and be influenced well. Culture is the soul of any society or country. Everyone is proud of one's culture and heritage. Any society is recognised by its cultural activities and folklores etc. It is quite natural that a person always wants to be associated to its culture. (Dr. Deep,D.,1983:9). The contents in Shri Guru Granth Sahib make it clear that we must not involve ourselves in worthless blind faiths and superstitions rather we should try to enlighten ourselves with God's Name. 
Hence we see that going through Guru Nanak's tradition of music we find a very good and authentic approach to know our culture. So to have a glance at the folklores of those days, one must have knowledge of the musical hymns of Sri Guru Granth Sahib.

\section{REFERED SOURCES}

Deep, Devender (1983). Guru Granth Sahib Vich Sankalit Guru Nanak Bani Vich Bharti Sabhyacar Da Chitran. Bhasha Vibhag, Punjab.

Joshi, Jeet Singh. (2004). Sabhyachar ate Lokdhara de Mool Sarokar. Lahore Book shop, Ludhiana.

Mansukhani, Gobind Singh. (1982). Indian Classical Music and Sikh Kirtan .

Music of Punjab. www.sikh-heritage.com. (http://www.sikhheritage.co.uk/arts/musicPunjab/Music\%20of\%20Punjab) accessed on 23.1.2021.

Singh Sukhwinder. (2003). Lok vaaran Ate Adhyatamak Vaaran di Drishti Te Swaroop. Balwant Prakashan, Jallandhar.

Singh, Prem Prakash. (1969). Barah Maah Tukhari-Ik Vishleshan. Punjabi Univercity Patiala. 